\title{
ANALISIS MANFAAT KOPERASI, PENDAPATAN, DAN TINGKAT KESEJAHTERAAN ANGGOTA KOPERASI LEMBAGA KEUANGAN MIKRO AGRIBISNIS (LKM-A) GAPOKTAN SARI MAKMUR KECAMATAN METRO TIMUR KOTA METRO
}

\author{
(The Analysis of Benefits, Income, and Welfare Level of LKM-A Gapoktan Sari Makmur \\ Cooperative's Member in East Metro Subdistrict, Metro City)
}

Dewi Lestari Putri, Dyah Aring Hepiana Lestari, Eka Kasymir

Jurusan Agribisnis, Fakultas Pertanian, Universitas Lampung, Jl. Prof. Dr. Soemantri Brojonegoro No. 1 Bandar Lampung 35145, Telp. 082116326908, e-mail: lestaridewi169@gmail.com

\begin{abstract}
This research aims to analyze the cooperative economic and noneconomic benefits received by members of LKM-A Gapoktan Sari Makmur Cooperative, the household income of cooperative members, and welfare level of cooperative members. This research was conducted by case study method in LKM-A Gapoktan Sari Makmur Cooperative, East Metro subdistrict. The locations were selected purposively. Data was collected from January to February 2018. The 42 research samples were taken by simple random sampling. Data was analyzed by the economic benefits of cooperative analysis, analysis of noneconomic benefits using Customer Satisfaction Index and Importance Performance Analysis, the household income of cooperative members, and analysis of welfare level. The results showed that the economic benefits received cooperative members was on low category and members were satisfied with the service of cooperative and fulfilled their needs. The household income of cooperative members was on high category. All of cooperative members considered as welfare families.
\end{abstract}

Key word : benefits, cooperative, income, welfare

\section{PENDAHULUAN}

Menurut Badan Pusat Statistik (2017) sektor pertanian memiliki kontribusi tertinggi setelah industri pengolahan, yaitu sebesar 13,44 persen terhadap Produk Domestik Bruto (PDB) di Indonesia. Akan tetapi, masih banyak petani yang kesulitan dalam menjalankan usahataninya karena mengalami masalah permodalan. Masalah itu mendorong munculnya kebijakan oleh Kementerian Pertanian tentang pembinaan kelembagaan petani dengan menumbuhkan Lembaga Keuangan Mikro Agribisnis (LKM-A).

Pengembangan LKM-A dilakukan melalui program Pengembangan Usaha Agribisnis Pedesaan (PUAP) dengan cara memberikan bantuan modal usaha untuk petani. Sebelum menjalankan kegiatan usaha, LKM-A harus memiliki izin usaha dari Otoritas Jasa Keuangan (OJK) dengan salah satu syarat, yaitu memiliki badan hukum terlebih dahulu. Hal itu sesuai dengan Undang-undang RI No 1 tahun 2013 pasal 4 tentang Lembaga Keuangan Mikro (LKM) yang menyatakan bahwa salah satu syarat pendirian LKM adalah memiliki badan hukum berupa Perseroan Terbatas (PT) atau koperasi (Kementerian Pertanian 2014).
Menurut Soetrisno (2001) dalam Harsoyo (2006) salah satu lembaga yang dapat mendukung perkembangan pertanian sekaligus perekonomian Indonesia adalah koperasi. Koperasi dinilai sebagai organisasi ekonomi untuk kesejahteraan sosial milik para anggota dan diapresiasikan sebagai agen pemerataan pendapatan.

Persentase jumlah koperasi tidak aktif di Provinsi Lampung tahun 2016 yang mencapai 44 persen menunjukkan bahwa banyak koperasi yang tidak melanjutkan kegiatannya. Salah satu kota/kabupaten di Provinsi Lampung yang memiliki jumlah koperasi tidak aktif lebih banyak dibandingkan jumlah koperasi aktif adalah Kota Metro. Kecamatan Metro Timur berada di urutan ke dua berdasarkan jumlah koperasi terbanyak di Kota Metro dengan persentase koperasi tidak aktif mencapai 67,44 persen (Dinas Koperasi dan UMKM Provinsi Lampung 2016).

Salah satu koperasi di Kecamatan Metro Timur adalah Koperasi LKM-A Gapoktan Sari Makmur. Koperasi ini berawal dari gapoktan yang terbentuk sejak tahun 2009, kemudian memperoleh dana PUAP pada tahun 2011. Dana tersebut dimanfaatkan oleh para pengurus dan anggota gapoktan untuk mengembangkan gapoktan 
menjadi koperasi simpan pinjam. Hal itu bertujuan agar para anggota dapat memenuhi modal usahatani yang sering tidak tercukupi. Pada tahun 2016, Koperasi LKM-A Gapoktan Sari Makmur berhasil didirikan dan memperoleh badan hukum dari Dinas Koperasi dengan nomor 518/02/D6.02/BH/XI/II/2016. Setelah itu, koperasi memperoleh izin usaha dari OJK dengan nomor izin usaha KEP-74/NB.123/2016.

Sebagai anggota koperasi, anggota menerima manfaat ekonomi koperasi (MEK) dan manfaat non ekonomi. MEK yang diterima anggota berupa Sisa Hasil Usaha (SHU) dan selisih bunga pinjaman. MEK dapat memberikan kontribusi pada pendapatan rumah tangga dan kesejahteraan anggota. Sementara itu, manfaat non ekonomi yang diukur dengan tingkat kepuasan akan berpengaruh terhadap keberlanjutan koperasi. Berdasarkan uraian tersebut, maka tujuan penelitian ini adalah menganalisis manfaat ekonomi dan non ekonomi koperasi, menganalisis pendapatan rumah tangga anggota koperasi, dan menganalisis tingkat kesejahteraan anggota koperasi.

\section{METODE PENELITIAN}

Penelitian ini dilaksanakan di Koperasi LKM-A Gapoktan Sari Makmur Kecamatan Metro Timur Kota Metro dengan menggunakan metode studi kasus. Lokasi ditentukan secara sengaja (purposive) dengan pertimbangan bahwa koperasi ini merupakan satu-satunya koperasi yang aktif di Kota Metro serta memiliki badan hukum dari Dinas Koperasi dan OJK. Pengambilan data dilakukan pada bulan Januari - Februari 2018.

Anggota Koperasi LKM-A Gapoktan Sari Makmur berjumlah 94 orang. Penentuan jumlah sampel mengacu pada Sugiarto (2003) dengan rumus sebagai berikut:

$\mathrm{n}=\frac{\mathrm{N} \mathrm{Z}^{2} \mathrm{~S}^{2}}{\mathrm{~N} \mathrm{~d}^{2}+\mathrm{Z}^{2} \mathrm{~s}^{2}}$

Keterangan :

$\mathrm{n}=$ Jumlah sampel

$\mathrm{N}=$ Jumlah populasi (anggota Koperasi LKM-A Gapoktan Sari Makmur)

$\mathrm{Z}=$ Tingkat kepercayaan $(95 \%=1,96)$

$S^{2}=$ Variasi sampel $(5 \%=0,05)$

$\mathrm{d}=$ Derajat penyimpangan $(5 \%=0,05)$

Berdasarkan rumus Sugiarto (2003) dapat ditentukan jumlah sampel sebagai berikut:

$$
\mathrm{n}=\frac{94(1,96)^{2}(0,05)}{(94)(0,05)^{2}+(1,96)^{2}(0,05)}
$$

$\mathrm{n}=42$ responden

Metode pengambilan sampel dilakukan dengan metode acak sederhana (simple random sampling). Data yang dikumpulkan dalam penelitian ini adalah data primer dan sekunder. Data primer diperoleh melalui wawancara langsung dengan anggota koperasi. Data sekunder diperoleh dari studi literatur, laporan-laporan, publikasi, dan pustaka lainnya yang berhubungan dengan penelitian ini, serta lembaga/instansi terkait.

\section{Analisis Manfaat Koperasi}

Manfaat koperasi terdiri dari MEK dan manfaat non ekonomi. MEK yang diterima anggota dihitung dari MEK tunai berupa SHU dan MEK diperhitungkan berupa selisih bunga pinjaman.

Sementara itu, manfaat non ekonomi (tingkat kepuasan) anggota koperasi diukur melalui seperangkat pertanyaan dengan skala Likert dan disertai lima alternatif jawaban (5=sangat memuaskan, 4=memuaskan, $3=$ cukup memuaskan, 2=kurang memuaskan, 1=tidak memuaskan). Seperangkat pertanyaan tersebut digunakan untuk menggambarkan tingkat kepuasan anggota terhadap pelayanan yang diberikan koperasi dari aspek tampilan fisik (tangibles), keterandalan (reliability), daya tanggap (responsiveness), kemampuan dalam memberikan jaminan (assurance), dan kemampuan memberikan perhatian personal (empathy). Tingkat kepuasan juga akan dinilai dari terpenuhinya kebutuhan anggota berdasarkan hierarki kebutuhan Maslow yang terdiri dari kebutuhan biologis, rasa aman, sosial, penghargaan diri, dan aktualisasi diri

Seperangkat pertanyaan tersebut diuji validitas dan reliabilitas terlebih dahulu. Menurut Umar (2003) uji validitas digunakan untuk menilai sejauh mana data yang ada pada kuesioner dapat mengukur apa yang akan diukur, sedangkan uji reliabilitas berfungsi untuk menunjukkan sejauh mana hasil pengukuran relatif konsisten apabila alat ukur digunakan berulang kali. Pada penelitian ini, hasil uji reliabilitas dan validitas kuesioner yang dilakukan terhadap 30 responden menunjukkan bahwa semua item pertanyaan adalah reliabel dan valid. 
Selanjutnya, dilakukan analisis tingkat kepuasan anggota koperasi menggunakan Analisis Customer Satisfaction Index (CSI) dan Importance Performance Analysis (IPA). Analisis CSI menggambarkan persentase kepuasan responden dengan lima kategori nilai (nilai CSI 0\%-34\% = tidak puas, $35 \%-50 \%=$ kurang puas, $51 \%-65 \%=$ cukup puas, $66 \%-80 \%=$ puas, $81 \%-100 \%=$ sangat puas). IPA digunakan untuk menggambarkan perbandingan antara kinerja koperasi dengan harapan anggota akan kinerja yang seharusnya ada. Total skor rata-rata pada atribut kepentingan dan kinerja diplotkan ke dalam Diagram Kartesius dengan empat kuadran, yaitu prioritas utama, pertahankan prestasi, prioritas rendah, dan berlebihan (Supranto 2006).

\section{Analisis Pendapatan Rumah Tangga}

Menurut Sajogyo (1997) pendapatan rumah tangga berasal dari berbagai sumber pendapatan yang secara matematis ditulis sebagai berikut:

$\mathrm{Prt}=\mathrm{P}_{\text {on farm }}+\mathrm{P}_{\text {off farm }}+\mathrm{P}_{\text {non farm }}+\mathrm{MKE}_{\text {tunai }} \ldots$...

Secara matematis, perhitungan pendapatan usahatani dapat ditulis sebagai berikut:

$\pi=Y . P y-\Sigma X i . P x i$

Keterangan:

$\pi=$ Pendapatan $(\mathrm{Rp})$

$\mathrm{Y}=$ Hasil produksi $(\mathrm{Kg})$

$\mathrm{Py}=$ Harga hasil produksi $(\mathrm{Rp})$

$\mathrm{Xi}=$ Faktor produksi $(\mathrm{i}=1,2,3, \ldots, \mathrm{n})$

Pxi $=$ Harga faktor produksi ke-i $(\mathrm{Rp})$

Selanjutnya, dilakukan analisis nisbah penerimaan dan biaya sebagai berikut:

$\mathrm{R} / \mathrm{C}=\mathrm{PT} / \mathrm{BT}$

Keterangan:

$\mathrm{R} / \mathrm{C}=$ Nisbah penerimaan dengan biaya

$\mathrm{PT}=$ Penerimaan total

$\mathrm{BT}=$ Biaya total petani

Kriteria pengukuran:

1. Jika $R / C>1$, maka usahatani menguntungkan

2. Jika $\mathrm{R} / \mathrm{C}=1$, maka usahatani impas

3. Jika $\mathrm{R} / \mathrm{C}<1$, maka usahatani mengalami kerugian

\section{Analisis Tingkat Kesejahteraan}

Tingkat kesejahteraan anggota diukur berdasarkan kriteria Badan Pusat Statistik (2014). Kriteria tersebut mengamati tingkat kesejahteraan dari berbagai aspek yang spesifik, yaitu kependudukan, kesehatan dan gizi, pendidikan, ketenagakerjaan, taraf dan pola konsumsi, perumahan dan lingkungan, serta sosial dan lain-lain. Klasifikasi kesejahteraan yang digunakan terdiri dari dua, yaitu skor antara $7-14$ menunjukkan rumah tangga belum sejahtera, sedangkan skor antara 15 21 menunjukkan rumah tangga sejahtera.

\section{HASIL DAN PEMBAHASAN}

\section{Karakteristik Responden}

Karakteristik responden dalam penelitian ini dilihat berdasarkan umur, jenis kelamin, tingkat pendidikan, pengalaman berkoperasi, pengalaman berusahatani, pekerjaan sampingan, dan luas lahan. Sebesar 55 persen responden tersebar pada kelompok umur 29 - 46 tahun (usia produktif) dengan tingkat pendidikan rata-rata $\mathrm{SD}$ dan memiliki tanggungan keluarga sebanyak $2-3$ orang (67\%). Jumlah responden laki-laki sama dengan perempuan karena anggota koperasi perempuan juga ikut membantu dalam menjalankan usahatani keluarga.

Semua responden telah menjadi anggota koperasi selama satu tahun dan belum pernah berkoperasi di tempat lain sebelumnya. Sebagian besar responden telah memiliki pengalaman berusahatani selama 3-14 tahun (48\%) dengan luas lahan 0,000,50 ha $(86 \%)$. Pekerjaan sampingan yang paling banyak adalah buruh non pertanian dan pedagang. Hal itu karena responden menganggap bahwa pekerjaan tersebut tidak memerlukan keahlian atau pendidikan khusus.

\section{Manfaat Ekonomi Koperasi}

Manfaat ekonomi adalah balas jasa koperasi terhadap anggotanya yang dapat diberikan secara tunai maupun diperhitungkan. MEK tunai diperoleh dari SHU yang diberikan koperasi sesuai dengan partisipasi anggota, seperti kehadiran di setiap kegiatan koperasi dan ketepatan waktu pembayaran simpanan wajib. MEK diperhitungkan diperoleh dari selisih bunga pinjaman. Pada tahun 2017, bunga pinjaman koperasi sebesar 8 persen. Bunga pinjaman pada alternatif tempat peminjaman anggota, antara lain meminjam tetangga $(0$ persen $)$, rentenir $(15$ 
persen), Bank Lampung (9 persen), BRI ( 9 persen), dan BNI (9 persen). Alternatif peminjaman dimanfaatkan saat koperasi tidak bisa meminjamkan dana kepada anggota (Kementerian Koordinator Bidang Perekonomian 2017).

Tabel 1 menunjukkan bahwa MEK tunai memiliki persentase yang lebih besar dibandingkan MEK diperhitungkan. Hasil MEK pada penelitian ini lebih kecil dibandingkan dengan penelitian Dinata, Lestari, dan Yanfika (2014) tentang pendapatan petani jagung anggota dan non anggota Koperasi Tani Makmur Desa Natar Kabupaten Lampung Selatan. Hal itu karena pada penelitian tersebut terdapat harga pinjaman sarana produksi, sedangkan pada penelitian ini hanya terdapat selisih bunga pinjaman. Selain itu, SHU yang diterima anggota pada penelitian ini lebih rendah karena kondisi perekonomian koperasi yang belum stabil.

\section{Manfaat Non Ekonomi Koperasi}

Manfaat non ekonomi koperasi adalah balas jasa koperasi yang diukur berdasarkan tingkat kepuasan anggota untuk menunjukkan sejauh mana koperasi dapat memberikan pelayanan dan memenuhi kebutuhan para anggota. Tingkat kepuasan anggota dikategorikan ke dalam tiga kategori, yaitu kepuasan rendah, sedang, dan tinggi.

Tabel 2 menunjukkan bahwa tingkat kepuasan yang dirasakan anggota terhadap pelayanan koperasi termasuk kategori sedang (cukup puas). Hal itu karena terdapat aspek-aspek pelayanan yang dinilai memiliki kinerja kurang baik, seperti petugas pelayanan informasi yang tidak selalu siaga. Tingkat kepuasan yang dirasakan anggota terhadap terpenuhinya kebutuhan termasuk kategori tinggi (puas). Hal itu karena anggota menilai bahwa koperasi telah memberikan manfaat yang dapat membantu usaha anggota.

Tabel 1. Jumlah manfaat ekonomi yang diterima anggota Koperasi LKM-A Gapoktan Sari Makmur, tahun 2017

\begin{tabular}{lcc}
\hline \multicolumn{1}{c}{$\begin{array}{c}\text { Manfaat Ekonomi } \\
\text { Koperasi }\end{array}$} & Rata-rata (Rp) & Persentase (\%) \\
\hline $\begin{array}{l}\text { Tunai (SHU) } \\
\begin{array}{l}\text { Diperhitungkan } \\
\text { bunga pinjaman) }\end{array}\end{array}$ & $53.809,52$ & 78,66 \\
\hline Total & $14.595,24$ & 21,34 \\
\hline
\end{tabular}

Tabel 2. Tingkat kepuasan anggota Koperasi LKM-A Gapoktan Sari Makmur

\begin{tabular}{lcc}
\hline Kepuasan terhadap: & $\begin{array}{c}\text { Importance } \\
\text { (diharapkan) }\end{array}$ & $\begin{array}{c}\text { Performance } \\
\text { (dirasakan) }\end{array}$ \\
\hline $\begin{array}{l}\text { Pelayanan koperasi } \\
\begin{array}{l}\text { Terpenuhinya } \\
\text { kebutuhan anggota }\end{array}\end{array}$ & 4,514 (tinggi) & 3,477 (sedang) \\
\hline
\end{tabular}

Hasil penelitian ini memiliki perbedaan dengan penelitian Jalika, Lestari, dan Suryani (2016) tentang evaluasi keberhasilan KSUP MDIT Kabupaten Tanggamus, Lampung berdasarkan pendekatan tripartite. Penelitian tersebut menyebutkan bahwa tingkat kepuasan yang dirasakan anggota terhadap pelayanan koperasi termasuk kategori tinggi (puas).

Selanjutnya, tingkat kepuasan anggota koperasi dianalisis menggunakan analisis CSI. Pada analisis CSI, dilakukan perhitungan total dan ratarata skor dari setiap atribut pertanyaan terlebih dahulu. Setelah dilakukan perhitungan, diperoleh rata-rata nilai atribut kepentingan anggota terhadap pelayanan koperasi adalah 4,51. Nilai tersebut memiliki kesenjangan dengan rata-rata nilai kinerja yang hanya sebesar 3,48 . Aspek empathy memiliki selisih nilai terkecil, sedangkan aspek responsiveness memiliki selisih nilai terbesar. Total skor kepuasan terhadap pelayanan koperasi adalah 517,63 dengan total skor kepentingan sebesar 148,88 dan skor kinerja sebesar 114,74. Nilai-nilai tersebut dimasukkan ke dalam rumus sebagai berikut:

$\mathrm{CSI}=\frac{513,63}{5(148,88)} \times 100 \%=69,54 \%$

Nilai CSI 69,54 persen menunjukkan bahwa anggota puas terhadap pelayanan yang diberikan koperasi. Hasil penelitian ini sejalan dengan penelitian Seta, Lestari, dan Situmorang (2016) tentang manfaat ekonomi dan non ekonomi Koperasi Gunung Madu di PT Gunung Madu Plantations Kabupaten Lampung Tengah. Penelitian tersebut menyebutkan bahwa anggota merasa puas terhadap pelayanan koperasi dengan nilai 70,80 persen.

Kemudian, dilakukan pula analisis CSI terhadap terpenuhinya kebutuhan anggota. Setelah dilakukan perhitungan, diperoleh rata-rata nilai atribut kepentingan anggota terhadap terpenuhinya kebutuhan adalah 4,53. Nilai tersebut memiliki kesenjangan dengan rata-rata nilai kinerja yang hanya sebesar 3,70. Aspek kebutuhan fisiologis 
memiliki selisih nilai terkecil, sedangkan aspek kebutuhan keamanan dan keselamatan memiliki selisih nilai terbesar. Total skor kepuasan terhadap terpenuhinya kebutuhan adalah 369,13 dengan total skor kepentingan sebesar 99,71 dan skor kinerja sebesar 81,40. Nilai-nilai tersebut dimasukkan ke dalam rumus sebagai berikut:

$$
\mathrm{CSI}=\frac{99,71}{5(369,13)} \times 100 \%=74,04 \%
$$

Nilai CSI 74,04 persen menunjukkan bahwa anggota merasa puas sebagai anggota koperasi. Nilai kepuasan ini lebih tinggi dibandingkan nilai kepuasan terhadap pelayanan anggota. Koperasi diharapkan terus meningkatkan dan memperbaiki kinerja, sehingga anggota merasa lebih puas menjadi bagian dari koperasi.

Setelah dilakukan perhitungan CSI, dilakukan analisis untuk membandingkan kepentingan dan kinerja koperasi menggunakan IPA. Setiap kuadran pada Diagram Kartesius pada Gambar 1 dan 2 akan menunjukkan kondisi koperasi yang berbeda. Kuadran I menunjukkan aspek yang dianggap penting oleh anggota, tetapi koperasi mempunyai kinerja buruk dalam aspek tersebut. Koperasi harus berupaya meningkatkan kinerja dalam aspek-aspek tersebut sehingga performance atribut akan meningkat.

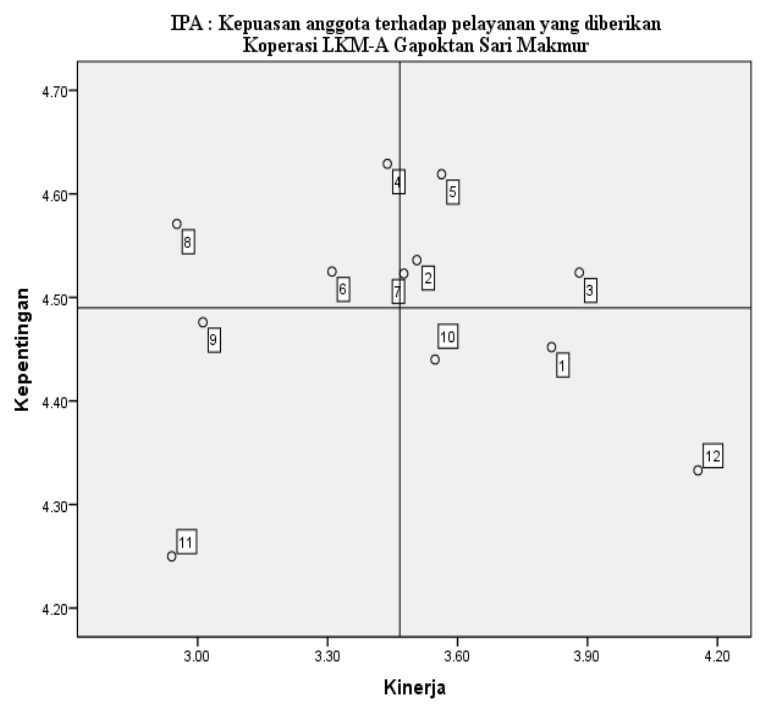

Gambar 1. Diagram IPA kepuasan anggota terhadap pelayanan yang diberikan Koperasi LKM-A Gapoktan Sari Makmur, tahun 2017

Keterangan:

T1 (1) : Kondisi prasarana dan sarana kantor

T2 (2) : Fasilitas penunjang

T3 (3) : Dukungan petugas pelayanan

R1 (4) : Kecepatan dalam pelayanan

R2 (5) : Ketepatan dalam pelayanan
R3 (6) : Kemampuan dan kesigapan pelayanan

S1 (7) : Ketanggapan petugas pelayanan

S2 (8) : Kemampuan memberikan informasi

A1 (9) : Kesopanan dalam pelayanan

A2 (10) : Pemahaman dan pengetahuan petugas

E1 (11) : Perhatian petugas dalam melayani

E2 (12) : Akses terhadap petugas pelayanan

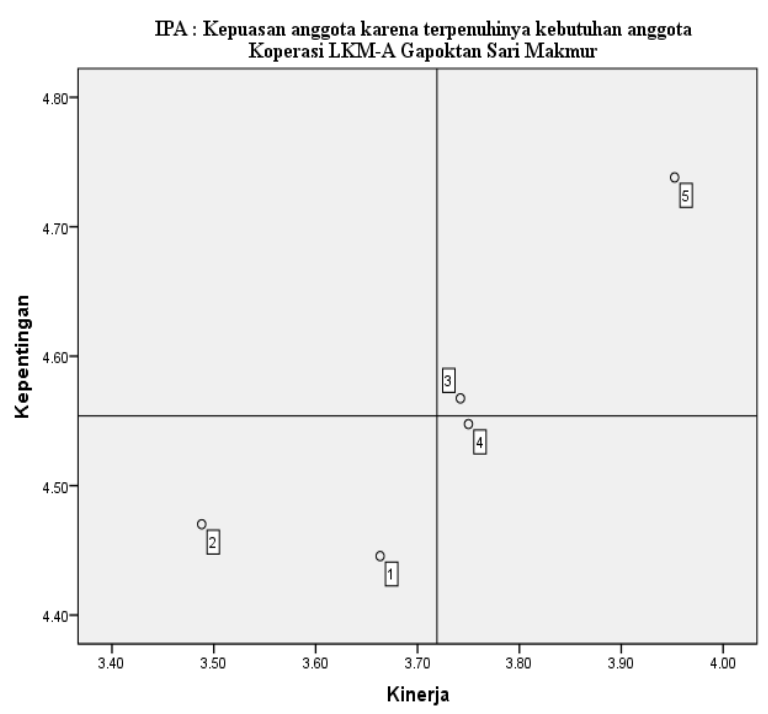

Gambar 2. Diagram IPA kepuasan anggota terhadap terpenuhinya kebutuhan anggota Koperasi LKM-A Gapoktan Sari Makmur, tahun 2017

Keterangan:

P1 (1) : Kebutuhan fisiologis

P2 (2) : Kebutuhan keamanan dan keselamatan

P3 (3) : Kebutuhan sosial

P4 (4) : Kebutuhan penghargaan

P5 (5) : Kebutuhan aktualisasi diri

Kuadran II menunjukkan aspek yang dianggap sangat penting dan sangat memuaskan karena koperasi sudah mempunyai kinerja baik dalam aspek tersebut. Koperasi harus tetap berkonsentrasi untuk mempertahankan aspekaspek tersebut sehingga anggota tetap merasa puas. Kuadran III menunjukkan aspek tertentu yang tidak terlalu dianggap penting oleh anggota dengan kinerja koperasi yang juga buruk. Aspek-aspek tersebut memiliki pengaruh sangat kecil terhadap manfaat yang dirasakan anggota, sehingga dapat diabaikan.

Kuadran IV menunjukkan aspek tertentu yang tidak terlalu dianggap penting oleh anggota, tetapi koperasi mempunyai kinerja baik dalam aspek tersebut. Biaya yang digunakan untuk menunjang aspek-aspek yang masuk ke dalam kuadran IV dapat dikurangi agar dapat menghemat biaya pengeluaran koperasi.

Hasil penelitian ini memiliki perbedaan dengan penelitian Jalika, Lestari, dan Suryani (2016) tentang evaluasi keberhasilan KSUP MDIT 
Kabupaten Tanggamus, Lampung berdasarkan pendekatan tripartite. Penelitian tersebut menyatakan bahwa aspek yang terletak pada kuadran I, yaitu kondisi prasarana dan sarana kantor koperasi, fasilitas penunjang, dukungan petugas pelayanan, serta kebutuhan ikut serta. Aspek yang masuk ke dalam kuadran II, yaitu perhatian petugas, akses terhadap petugas, kebutuhan akan keamanan, keselamatan, penghargaan, dan aktualisasi diri. Perbedaan juga terdapat pada aspek-aspek yang masuk ke dalam kuadran III dan IV.

\section{Pendapatan Rumah Tangga Anggota Koperasi LKM-A Gapoktan Sari Makmur}

Pendapatan rumah tangga diperoleh dari semua sumber pendapatan anggota. Pada lokasi penelitian, kegiatan usahatani (on farm) utama responden adalah tanaman padi (MT I), jagung (MT II), dan padi (MT III). Tanaman padi dan jagung ditanam secara bergantian setiap empat bulan dengan rata-rata luas lahan anggota adalah 0,42 ha. Tabel 5 (terlampir) menunjukkan bahwa pendapatan tertinggi diperoleh dari usahatani padi (MT I).

Pendapatan terendah diperoleh pada usahatani jagung (MT III). Perbedaan pendapatan tersebut terjadi karena harga jual dan produksi jagung yang lebih rendah. Nilai R/C pada musim tanam I, II, maupun III lebih besar dari 1, berarti usahatani padi dan jagung anggota menguntungkan.

Selain memperoleh pendapatan dari on farm utama, beberapa anggota memiliki usaha lain, yaitu ternak kambing. Terdapat tiga responden yang memiliki usaha ternak kambing dengan rata-rata pendapatan sebesar Rp926.190,48 per tahun. Selain itu, terdapat dua responden yang memiliki kegiatan di luar usahatani (off farm) berupa penjualan jamu dan keripik. Kegiatan di luar pertanian (non farm) responden cukup bervariasi, antara lain pedagang, buruh non pertanian, penjahit, PNS, reparasi kendaraan, aparatur desa, dan asisten rumah tangga.

Tabel 3 menunjukkan bahwa pendapatan on farm memiliki kontribusi terbesar untuk pendapatan rumah tangga responden karena usahatani padi dan jagung merupakan sumber pendapatan utama untuk semua responden. Pendapatan dari MEK tunai memiliki kontribusi terkecil karena SHU yang diterima responden masih tergolong rendah. Hasil penelitian tersebut sejalan dengan penelitian Dinata, Lestari, dan Yanfika (2014) tentang pendapatan petani jagung anggota dan non anggota Koperasi Tani Makmur Desa Natar Kabupaten Lampung Selatan. Penelitian tersebut menyebutkan bahwa sumber pendapatan yang paling berkontribusi terhadap pendapatan rumah tangga adalah pendapatan on farm, sedangkan MEK tunai memiliki kontribusi terendah. Akantetapi, total pendapatan rumah tangga pada penelitian ini lebih tinggi dibandingkan pada penelitian tersebut, yaitu $\mathrm{Rp} 19.670 .358,19,00$ pertahun. Perbedaan tersebut terjadi akibat adanya perbedaan lokasi penelitian dan pola tanam.

\section{Tingkat Kesejahteraan Rumah Tangga Anggota Koperasi LKM-A Gapoktan Sari Makmur}

Tingkat kesejahteraan diperoleh dari total rata-rata skor setiap indikator. Tabel 4 menunjukkan bahwa total rata-rata skor semua responden adalah 16,20 yang berarti rumah tangga sejahtera. Indikator perumahan dan lingkungan memiliki total rata-rata skor tertinggi karena sebagian besar responden telah memiliki rumah sendiri dan permanen, fasilitas WC, sumber air minum yang bersih, dan tempat pembuangan sampah. Indikator sosial dan lain-lain memiliki total rata-rata skor terendah karena sebagian besar responden tidak pernah melakukan perjalanan jauh. Selain itu, tidak ada responden yang memahami penggunaan komputer.

Hasil penelitian ini sejalan dengan penelitian Saputra, Widjaja, dan Kalsum (2016) tentang pendapatan dan kesejahteraan anggota KSP Tani Makmur Kecamatan Natar Kabupaten Lampung Selatan. Penelitian tersebut menyatakan bahwa semua responden masuk ke dalam kategori sejahtera dengan skor 17,90. Perbedaan skor kesejahteraan tersebut terjadi karena adanya perbedaan kondisi responden di lokasi penelitian.

\section{KESIMPULAN}

Manfaat ekonomi koperasi dari SHU dan selisih bunga pinjaman yang diterima anggota koperasi masih tergolong rendah. Akan tetapi, pembagian SHU telah dilakukan secara adil. Manfaat non ekonomi yang diukur dengan tingkat kepuasan menunjukkan bahwa anggota merasa puas terhadap pelayanan koperasi dan pemenuhan kebutuhan anggota. Rata-rata pendapatan rumah tangga yang diterima anggota koperasi dalam satu tahun sudah tergolong tinggi sebesar Rp33.534.916,67 per tahun. Hasil pada Tabel 4 menunjukkan bahwa semua anggota koperasi berada pada kategori rumah tangga sejahtera. 
Tabel 3. Rata-rata pendapatan rumah tangga anggota Koperasi LKM-A Gapoktan Sari Makmur tahun 2017

\begin{tabular}{lrr}
\hline \multicolumn{1}{c}{ Sumber Pendapatan } & $\begin{array}{c}\text { Rata-rata } \\
\text { Pendapatan } \\
(\mathrm{Rp})\end{array}$ & $\begin{array}{r}\text { Persentase } \\
(\%)\end{array}$ \\
\hline Pendapatan on farm & $29.066 .821,43$ & 86,68 \\
Pendapatan off farm & $416.666,67$ & 1,24 \\
Pendapatan non farm & $3.997 .619,05$ & 11,92 \\
MEK tunai & $53.809,52$ & 0,16 \\
\hline Jumlah & $33.534 .916,67$ & 100,00 \\
\hline
\end{tabular}

Tabel 4. Skor indikator kesejahteraan anggota Koperasi LKM-A Gapoktan Sari Makmur

\begin{tabular}{lc}
\hline \multicolumn{1}{c}{ Indikator } & Rata-rata Skor \\
\hline Kependudukan & 2,19 \\
Kesehatan dan gizi & 2,38 \\
Pendidikan & 2,63 \\
Ketenagakerjaan & 2,07 \\
Taraf dan pola konsumsi & 2,42 \\
Perumahan dan lingkungan & 2,83 \\
Sosial dan lain-lain & 1,68 \\
\hline Total & 16,20 \\
\hline
\end{tabular}

*Kriteria Badan Pusat Statistik, 2014

\section{DAFTAR PUSTAKA}

Badan Pusat Statistik. 2014. Indikator Kesejahteraan Rakyat. https://www.bps. go.id/publication/2014/09/08/525d6d3319233 b512977ae21/indikator-kesejahteraan-rakyat2014.html. [20 Oktober 2017]. 2017. PDB Triwulanan Atas Dasar Harga Konstan 2010 Menurut Lapangan Usaha 2014-2017. https:// www.bps.go.id/linkTableDinamis/view/id/827 . [19 Oktober 2017].

Dinas Koperasi dan UMKM Provinsi Lampung. 2016. Jumlah Koperasi Aktif dan Tidak Aktif Menurut Kota/Kabupaten di Provinsi Lampung Tahun 2016. Bandar Lampung.

Dinata AS, Lestari DAH, dan Yanfika H. 2014. Pendapatan petani jagung anggota dan nonanggota Koperasi Tani Makmur Desa Natar Kabupaten Lampung Selatan. Jurnal Ilmu-Ilmu Agribisnis. 2 (3): 211-212. http://jurnal.fp.unila.ac.id/index.php/JIA/articl e/viewFile/802/732. [3 Juni 2018].
Harsoyo Y. 2006. Ideologi Koperasi Menatap Masa Depan. Pustaka Widyatama. Yogyakarta.

Jalika TU, Lestari DAH, dan Suryani A. 2016. Evaluasi keberhasilan Koperasi Serba Usaha Peternak Motivasi Do'a Ikhtiar Tawakkal (KSUP MDIT) Kabupaten Tanggamus, Lampung berdasarkan pendekatan tripartite. Jurnal Ilmu-Ilmu Agribisnis. 4 (4): 420-421. http://jurnal.fp.unila.ac.id/index.php/JIA/ar ticle/viewFile/1524/1378. [22 Oktober 2017].

Kementerian Koordinator Bidang Perekonomian. 2017. Evolusi KUR. http://kur.ekon.go.id /evolusi-kur. [10 Juli 2018].

Kementerian Pertanian. 2014. Pedoman Pengembangan LKM-A Pada Gapoktan PUAP Tahun 2014. Jakarta. http://psp. pertanian.go.id/assets/file/2014/Pedoman $\% 20$ Pengembangan\%20LKMA\%202014.pdf. [20 Oktober 2017].

Sajogyo. 1997. Garis Kemiskinan dan Kebutuhan Minimum Pangan. LPSB IPB. Bogor.

Saputra AARE, Widjaja S, dan Kalsum U. 2016. Pendapatan dan kesejahteraan anggota KSP Tani Makmur Kecamatan Natar Kabupaten Lampung Selatan. Jurnal Ilmu-Ilmu Agribisnis. 4 (2): 167. http://jurnal.fp.unila .ac.id/index.php/JIA/article/viewFile/1233/11 30. [22 Oktober 2017].

Seta AP, Lestari DAH, dan Situmorang S. 2016. Manfaat ekonomi dan non ekonomi Koperasi Gunung Madu (KGM) di PT Gunung Madu Plantations (PT GMP) Kabupaten Lampung Tengah. Jurnal Ilmu-Ilmu Agribisnis. 4 (2): 168-169. http://jurnal.fp.unila.ac.id/index .php/JIA/article/viewFile/1234/1131. [6 Juni 2017].

Sugiarto. 2003. Teknik Sampling. Gramedia. Jakarta.

Supranto J. 2006. Pengukuran Tingkat Kepuasan Pelanggan untuk Menaikkan Pangsa Pasar. Rineka Cipta. Jakarta.

Umar H. 2003. Metode Riset Bisnis. PT Gramedia Pustaka Utama. Jakarta. 
Tabel 3. Pendapatan dan R/C usahatani anggota koperasi pada usahatani padi (MT I), jagung (MT II), dan padi (MT III) per 1 hektar tahun 2017

\begin{tabular}{|c|c|c|c|c|c|c|c|c|c|}
\hline \multirow[b]{2}{*}{ No } & \multirow[b]{2}{*}{ Uraian } & \multirow[b]{2}{*}{ Sat } & \multirow{2}{*}{$\begin{array}{l}\text { Harga } \\
\text { (Rp/sat) }\end{array}$} & \multicolumn{3}{|c|}{ Jumlah } & \multicolumn{3}{|c|}{ Nilai (Rp) } \\
\hline & & & & $\begin{array}{l}\text { MT I } \\
\text { (Padi) }\end{array}$ & $\begin{array}{c}\text { MT II } \\
\text { (Jagung) }\end{array}$ & $\begin{array}{l}\text { MT III } \\
\text { (Padi) }\end{array}$ & $\begin{array}{l}\text { MT I } \\
\text { (Padi) }\end{array}$ & $\begin{array}{c}\text { MT II } \\
\text { (Jagung) }\end{array}$ & $\begin{array}{l}\text { MT III } \\
\text { (Padi) }\end{array}$ \\
\hline \multirow[t]{5}{*}{1.} & Penerimaan & & & & & & & & \\
\hline & Produksi & & & & & & & & \\
\hline & - Padi & $\mathrm{Kg}$ & $8.000,00$ & 5.24376 & 402211 & 4.45295 & 41950113,38 & 1005527211 & 38.29535147 \\
\hline & - Jagung & $\mathbf{n g}$ & $2.500,00$ & & & & & & \\
\hline & - Padi & & $8.600,00$ & & & & & & \\
\hline \multirow[t]{28}{*}{2.} & Biaya Produksi & & & & & & & & \\
\hline & I. Biaya Tunai & & & & & & & & \\
\hline & Benih & & & & & & & & \\
\hline & $\begin{array}{l}\text { - Padi } \\
\text { - Jagung }\end{array}$ & $\mathrm{Kg}$ & $\begin{array}{l}5.000,00 \\
6.000,00\end{array}$ & 31,49 & 21,46 & 32,74 & $157.454,65$ & $128.741,50$ & $163.690,48$ \\
\hline & - Padi & & $5.000,00$ & & & & & & \\
\hline & Pupuk NPK & $\mathrm{Kg}$ & $2.300,00$ & 99,21 & 121,88 & 127,55 & $228.174,60$ & $280.328,80$ & $293.367,35$ \\
\hline & Pupuk TSP & $\mathrm{Kg}$ & $2.400,00$ & 113,38 & 90,70 & 124,72 & $272.108,84$ & $217.687,07$ & $299.319,73$ \\
\hline & Pupuk KCL & $\mathrm{Kg}$ & $3.000,00$ & 87,87 & 59,52 & 70,86 & $263.605,44$ & $178.571,43$ & $212.585,03$ \\
\hline & Pupuk Urea & $\mathrm{Kg}$ & $2.000,00$ & 269,27 & 232,43 & 274,94 & $538.548,75$ & $464.852,61$ & $549.886,62$ \\
\hline & Pupuk & & & & & & & & \\
\hline & Phonska & $\mathrm{Kg}$ & $2.700,00$ & 144,56 & 93,54 & 136,05 & $390.306,12$ & $252.551,02$ & $367.346,94$ \\
\hline & Gramoxone & Ltr & $60.000,00$ & 2,82 & 1,08 & 1,94 & $169.217,69$ & $64.625,85$ & $116.496,60$ \\
\hline & Fastac & $\mathrm{ml}$ & 100,00 & $1.077,10$ & 164,40 & 663,27 & $107.709,75$ & $16.439,91$ & $66.326,53$ \\
\hline & Metindo & $\mathrm{Kg}$ & $180.000,00$ & 0,27 & 0,43 & 0,75 & $48.469,39$ & $76.530,61$ & $135.204,08$ \\
\hline & Furadan & $\mathrm{Kg}$ & $25.000,00$ & 0,45 & 0,54 & 0,65 & $11.337,87$ & $13.463,72$ & $16.298,19$ \\
\hline & Regent & $\mathrm{ml}$ & 280,00 & 303,29 & 170,07 & 257,94 & $84.920,63$ & $47.619,05$ & $72.222,22$ \\
\hline & TKLK & HOK & $60.000,00$ & 39,93 & 28,85 & 40,77 & $2.395 .691,61$ & $1.730 .867,35$ & $2.446 .286,85$ \\
\hline & Pajak & $\mathrm{Rp}$ & & & & & $46.201,81$ & $46.201,81$ & $46.201,81$ \\
\hline & Irigasi & $\mathrm{Rp}$ & & & & & $255.952,38$ & 0,00 & $267.857,14$ \\
\hline & Pengangkutn & $\mathrm{Rp}$ & & & & & $261.904,76$ & $191.043,08$ & $274.943,31$ \\
\hline & Penggilingan & $\mathrm{Rp}$ & & & & & $4.195 .011,34$ & $1.005 .527,21$ & $3.829 .535,15$ \\
\hline & Total Biaya T & Inai & & & & & $9.426 .615,65$ & $4.715 .051,02$ & $9.157 .568,03$ \\
\hline & II. Biaya diperhit & ungkan & & & & & & & \\
\hline & TKDK & $\mathrm{HOK}$ & $60.000,00$ & 26,57 & 30,89 & 29,32 & $1.593 .962,59$ & $1.853 .316,33$ & $1.759 .353,74$ \\
\hline & Penyusutan & & & & & & & & \\
\hline & Alat & $\mathrm{Rp}$ & & & & & $124.625,22$ & $124.625,22$ & $124.625,22$ \\
\hline & Total Biaya D & perhitu & gkan & & & & $1.718 .587,81$ & $1.977 .941,55$ & $1.883 .978,96$ \\
\hline & III. Total Biaya & & & & & & $11.145 .203,45$ & $6.692 .992,57$ & $11.041 .546,99$ \\
\hline \multirow[t]{6}{*}{3.} & Pendapatan & & & & & & & & \\
\hline & I. Pendapatan & & & & & & & & \\
\hline & $\begin{array}{l}\text { atas Biaya } \\
\text { Tunai }\end{array}$ & $n$ & & & & & 3252340773 & 534022100 & 2013778345 \\
\hline & II. Pendapatan & $\pi p$ & & & & & $32.523 .491,13$ & $5.340 .221,09$ & $29.131 .183,45$ \\
\hline & atas Biaya & & & & & & & & \\
\hline & Total & $\mathrm{Rp}$ & & & & & $30.804 .909,93$ & $3.362 .279,54$ & $27.253 .804,48$ \\
\hline \multirow[t]{6}{*}{4.} & R/C Ratio & & & & & & & & \\
\hline & I. $\mathrm{R} / \mathrm{C}$ atas & & & & & & & & \\
\hline & Biaya & & & & & & & & \\
\hline & Tunai & & & & & & 4,45 & 2,13 & 4,18 \\
\hline & II. $\mathrm{R} / \mathrm{C}$ atas & & & & & & & & \\
\hline & Biaya Total & & & & & & 3,76 & 1,50 & 3,47 \\
\hline
\end{tabular}

